the lessons learnt that anyone could, and did use during the next war. This paper will be of special value to historians researching the guerrilla phase of the Anglo-Boer War.

Oliver's paper on the role of people in Australia opposed to the war is interesting. Previously it was known that there was opposition to the war, but here the nature of and the influence of this phenomenon is analysed. One gets to know the personalities, their motives and the impact that they had on Australian society. Another important aspect is the raising of funds in Australia during the war, which highlights how financial matters were influenced as a result of the war. This indicated a strengthening of ties with the empire, but also creating a stronger loyalty towards Australia. John Hirst discusses the impact of the political dimension of the war on Australia in the next paper. The war cemented the new federation and its manifestation can be traced to the establishment of an own military system, as is described in the last paper by Luke Trainor. What is also very important is how Australia fitted into the world wide defence system of the empire, not just with regards to South Africa, but also towards the rest of the world.

The Boer War, Army, Nation and Empire provides a different perspective of the war. It contributes to the understanding of the historical experience of especially Australians of the war. Thus, it leads to a better understanding of the world at the turn of the century and how it was influenced by events in South Africa.

Lt Col (Dr) C.J. Jacobs. Resident Historian, SA Army College, Thaba Tshwane, Pretoria

\title{
PEACE, PROFIT OR PLUNDER: THE PRIVATIZATION OF SECURITY IN WAR TORN AFRICAN SOCIETIES
}

J. Cilliers \& P. Mason (eds.)

Institute for Security Studies: 1999

245 Pages

Maps: Angola and Sierra Leone

Tables and Diagrams of Private Security Companies

Abbreviations

This publication is about a theme that is presently a rising issue of concern on the national security agendas of states and other bodies grappling with security issues. This concern takes place against the tendency of an increasing number of issues being dumped into the security dustbin. Privatisation of security holds both the potential to soften the security dilemmas of countries as well as to threaten the marginal security of weak states. The publication deals with both sides by pointing out the constructive as well as the destructive potential of the private security industry.

In an environment where the conceptual understanding of the security of countries are underdeveloped or, at the minimum, extremely complex, this publication strives towards creating some sense of understanding on at least one matter - that of private security vs the traditional role of the state. In addition its primary focus is 
upon Africa, a region that has to deal with the most severe and complicated matters of security.

The editors managed to open a window on the inner workings of private security firms, their origins and the shifting agendas of these actors as well as those of governments and non-governmental actors. In essence the editors outline the image of a complicated security environment where the traditional role of the state is eroded, very weak or non-existent and other measures find a fertile breeding ground as opportunities arise. Simultaneously the role of private security outside the state domain is outlined as well and in particular those factors contributing to its growth. This private-state overlap represents the essence of the difficulties raised within the publication

Turning to Africa, publication is a useful introduction to the security environment that acts as a backdrop to the involvement of private (military) security actors in a region where very little seems to adhere to accepted rules of state behaviour and governing. A major contribution of the focus on Africa is the extent to which the reasons for involvement quickly tend to become caught up in the insecurity enigmas of countries. This in turn impacts upon the preferred role and utility of private security companies. The interface between the personal power of ruling elite's, the attraction of private security firms and crossing the threshold into war fighting are the three main difficulties dealt with and alludes to the damaging image of private security firms.

Private security, as a service rendered by legitimate actors, seems to be a matter absconded by some governments, whilst viewed a contribution to dealing with extremely difficult insecurities by others, including non-governmental groups. The involvement of the private security industry, as outlined in the publication under discussion, portrays a picture of states, non-state actors and economic actors viewing private security as part of the solution to their insecurities or achieving their objectives. However, due to a general institutional or systems inability to accommodate the longer-term consequences of these relationships, the operational side partnerships become intricate. The reader becomes exposed to the way in which private security contributes to security on the continent, but stays controversial due to a plethora of difficulties in trying to deal with a new variable in the pursuit of security.

The editors managed to cover most of the scope of events and developments on the privatisation of security. By outlining the background to the phenomenon over time, contemporary happenings, the incompatibilities and legal issues as well as ending with some future views, they manage to present decision makers and other interested parties with a credible overview of the current state of affairs of both the private security industry as well African pathways into this environment.

The publication is a contemporary guide to the theme of private security and the contentious issue of possible migration into the war-fighting environment. Government decision-makers as well as executives in the private security industry could only benefit from studying this publication. It contains information and lessons that previously were scattered over the landscape of security literature. It is obvious that in South Africa and in Africa this publication most probably represents the most fundamental collection of information and opinions on the matter.

The negative side of the publication is that it is not entirely clear about the matter that the privatisation of security is not a threat to the security of states per se. It 
is both the tendency of private security actors to cross into the war-fighting environment and that of states (in Africa) to use private security potential for matters other than the national interest. Simultaneously non-state actors should be considered part of the problem if they use private security actors as a Trojan horse to cross into the war-fighting arena or undermine legitimate state interests. These are perhaps the only two matters that need to be reconsidered.

The publication contains interesting diagrams on the structure of private security firms. They reflect the scope, diversity as well as the independence of private security firms to play their role and adjust to the needs of the client - whether a state or a non-state actor such as MNC's. It creates the impression of an industry gearing itself towards an environment where it is to operate amongst equals and make use of business opportunities that might arise. Its corporate structure therefore should reflect the flexibility and adaptability to respond to both the current African-type needs as well as the more sophisticated customer. Lt Col François Vrey, Department of Military Strategy, University of Stellenbosch (SA
Military Academy)

\author{
MODERN STRATEGY \\ Colin Gray \\ Oxford University Press: Oxford, 1999. \\ 412pp \\ Preface \\ References and index
}

This recent publication by Colin Gray is perhaps the most modern source of information for understanding the realm of strategy, the current as well as the future strategic environment and its complexities. The publication represents three decades of intellectual property of one of the world's leading theorists on strategic theory - a phenomenon understood by very few decision makers, but in demand of their close and daily attention whilst grappling with its complexities in a demanding world. It is a publication in the words of the author '....[b]ut this work is neither a strategic history of the $20^{\text {th }}$ century nor a history of strategy in the twentieth century - rather Modern Strategy is principally about characteristically modern expressions of the ageless phenomena of strategy' The publication thus represents an effort to clarify and give enduring substance to the field of strategy as it increasingly becomes engulfed in rising layers of complexity.

Gray leads the reader down a logical pathway of strategic theory, its history and the future. Six questions are posed to shape the structure and arguments of the book. [1] How do the theory and practise of strategy interact? [2] What has the growing complexity of defence preparation and war meant for strategy? [3] Why is strategy so difficult? [4] If strategy and war has so many dimensions, is it probable that superiority in one/several such dimensions can deliver victory? [5] What has changed for strategy in the $20^{\text {th }}$ century and what has not? [6] What does the strategic experience of the $20^{\text {th }}$ century tell us about what is probably to come in the $21^{\text {st }}$ century? The dimensions of strategy are presented and in particular the important role 